\section{Built environment and social environment: associations with overweight and obesity in a sample of Brazilian adults}

\author{
Ambiente construído e ambiente social: \\ associações com o excesso de peso \\ em adultos
}
Ambiente construido y ambiente social: asociaciones con el exceso de peso en adultos

Gustavo Velásquez-Meléndez ${ }^{1}$

Larissa Loures Mendes 1

Cristina Maria Proença Padez 2

\footnotetext{
${ }_{1}$ Escola de Enfermagem, Universidade Federal de Minas Gerais, Belo Horizonte, Brasil.

2 Departamento de Antropologia, Universidade de Coimbra, Coimbra, Portugal.

Correspondence G. Velásquez-Meléndez Departamento de Enfermagem Materno Infantil e Saúde Escola de Enfermagem. Universidade Federal de Minas Gerais.

Av. Alfredo Balena 190, sala 400, Belo Horizonte, $M G$ 30130-100, Brasil. guveme@ufmg.br
}

\begin{abstract}
The aim of this study was to assess associations between the built environment and social environment and excess weight in an urban population. Participants were selected from the Surveillance System for Risk Factors for Chronic Diseases (VIGITEL). The study used data from the city of Belo Horizonte, Minas Gerais State, Brazil. A total of 3,425 interviews from the years 2008 and 2009 were used. Georeferenced data on parks, squares, and locations for physical exercise, population density, and food stores were used to assess the built environment. Description of the social environment used income and homicide rate for the neighborhood. Environmental variables associated independently with excess weight were population density, presence of parks, squares, and locations for physical exercise, and self-reported presence of locations for physical exercise. The findings show that residential neighborhood characteristics are associated with excess weight in urban adults.
\end{abstract}

Controlled Environment; Environment and Public Health; Obesity; Overweight

\section{Resumo}

O objetivo deste estudo foi avaliar as associações das variáveis do ambiente construído e social com o excesso de peso em uma população urbana. Os participantes foram selecionados com base no Sistema de Vigilância de Fatores de Risco para Doenças Crônicas (VIGITEL). O trabalho foi realizado com dados da cidade de Belo Horizonte, Minas Gerais, Brasil. Foram utilizadas 3.425 entrevistas referentes aos anos de $2008 e$ 2009. Informações georreferenciadas de parques, praças, lugares para a prática de atividade física, densidade populacional e estabelecimentos alimentares foram usadas para avaliar o ambiente construído. Para caracterizar o ambiente social foi utilizada renda e taxa de homicídio da vizinhança. As variáveis ambientais associadas independentemente com excesso de peso foram densidade populacional, presença de parques, praças e locais para a prática de atividade física e o autorrelato de locais para a prática de atividade física. As evidências deste estudo mostram que as características das vizinhanças onde as pessoas residem estão associadas ao excesso de peso de adultos do meio urbano.

Meio Ambiente Construído; Meio Ambiente e Saúde Pública; Obesidade; Sobrepeso 


\section{Introduction}

Obesity is a chronic illness with a complex etiology and multiple associated factors such as life habits and genetic and biological susceptibility 1 . Recently, the characteristics of the environment in which people live, including neighborhood socioeconomic status, availability and affordability of healthy foods, and opportunities for physical activity have been widely associated with the current obesity epidemic in various countries $2,3,4$. When such environments encourage physical inactivity and unhealthy food choices, they are described as obesogenic, i.e., responsible for promoting obesity 5 .

In this context, the current obesity epidemic has been related to four main factors: built environment; social environment; individual behavior; and individual biological factors 6 . The built environment can present opportunities for unhealthy eating, such as the absence of stores with fresh and healthy food produce and barriers to energy expenditure in daily routines $7,8,9$, such as absence of sidewalks along the streets for walking to and from places, low connectivity between streets, insufficient lighting, and neighborhoods with limited recreational facilities, which can hinder physical exercise 10 . In addition, neighborhoods with lower residential and population density, less connected streets, and low mixed land use are associated with increased risk of obesity 11,12,13,14,15,16.

In addition to the built environment, the social environment can also affect eating patterns and level of physical activity in neighborhoods and thereby contribute to weight increase. The social environment includes elements related to individual living conditions such as income, schooling, crime record, social support networks, and level of trust, which are associated with greater or lesser social disorder and social deprivation in the neighborhood 17. Thus, understanding the environment's role in the increased prevalence of obesity is fundamental for developing effective strategies to prevent this disease and thereby reduce its negative impacts on the population's health.

Various observational studies in recent decades have shown an increasing consensus concerning the existence of obesogenic environments $18,19,20$, but there is still controversy on the formalization, definition, measurement, and characterization of the environmental components related to weight gain and difficulties in defining the environments and the unit used to define neighborhood, where some studies used census tracts and others use boroughs, buffers, and other specific neighborhood units in countries where they are located 21,22,23,24.
Although obesogenic environments have been extensively studied in developed countries 23,24 , the theme needs to be explored in greater depth in Brazilian studies with the use of different methodologies, populations (children, adolescents, adults, and the elderly), and contexts (households, schools, and the workplace). The current study thus aimed to estimate associations between variables from the built and social environments and excess weight in an urban setting in Brazil.

\section{Methodology}

This was a cross-sectional, descriptive, and analytical epidemiological study using the VIGITEL database, with access granted by the Brazilian Ministry of Health 25,26. The project for implementation of the VIGITEL system was approved by the National Ethics Committee on Research in Humans under the Ministry of Health and was also approved by the Institutional Review Board of the Federal University in Minas Gerais (UFMG), case number 552/08.

The current study used data from the city of Belo Horizonte, capital of the State of Minas Gerais. The city is located in the Southeast of Brazil, with an area of $331 \mathrm{~km}^{2}$, population $2,365,151$, and population density 7,177 inhabitants $/ \mathrm{km}^{2}$ (Brazilian Institute of Geography and Statistics. Population Census 2010. http://www. ibge.gov.br).

This study used the interviews from the samples in the years 2008 and 2009 in the city of Belo Horizonte. Sampling of participants was done in two stages: (1) random selection of households with landline telephones and (2) selection of interviewees 18 years or older. For each Brazilian capital city, the VIGITEL system aims to obtain probabilistic samples of the population of adult residents in households served by a landline telephones, and sampling weights were subsequently assigned to the individuals interviewed by the system, with the aim of at least partially correcting biases resulting from non-universal coverage of the landline telephone system. This study considered 4,000 eligible interviews, of which 3,661 were used because they contained the data on weight and height. Of these, 131 interviews (3.6\%) were excluded, from participants with body mass index (BMI) less than $18.5 \mathrm{~kg} / \mathrm{m}^{2}$. There was an additional loss of 105 individuals due to locating errors in the data georeferencing process. The final sample thus consisted of 3,425 individuals.

Data were used from the standardized questionnaire conducted with a telephone interview, 
with information on demographics, weight, and height, all self-reported.

The dependent variable for the current study was BMI. BMI was categorized in two groups: normal $\left(18.5 \mathrm{~kg} / \mathrm{m}^{2} \leq \mathrm{BMI}<25 \mathrm{~kg} / \mathrm{m}^{2}\right)$ and excess weight (BMI $\geq 25 \mathrm{~kg} / \mathrm{m}^{2}$ ) according to the values proposed by the World Health Organization (WHO) 27 . Weight and height were self-reported. These data have been widely used in epidemiological studies 28 and were previously validated for Brazilian adults 29 .

The environmental variables selected for this study were: population density, supermarkets and hypermarkets, fruit and vegetable stores, parks, public squares, and places for practicing physical exercise, homicide rate, and mean family income (Table 1).

To verify the spatial distribution of variables and analyze them, the VIGITEL was geocoded using the postal codes of the participants' homes, obtaining values for latitude and longitude based on the centroid of the street corresponding to the address's postal code. Individuals were later clustered according to the coverage age where they resided, also based on latitude and longitude.

Characterization of the built environment and social environment used the development of a geocoded base, incorporating each participant's personal data into the sample. An existing, updated list was then used, based on the registries of the current addresses of supermarkets and hypermarkets in the city. The latter was used as an indicator of the availability of different foods. Georeferenced data on parks, public squares, places for physical exercise, and population density were also used to comprise the data on the built environment. These data were provided by the Belo Horizonte Municipal Company for Information and Information Technology (Prodabel).

The social environment was characterized with georeferenced data on the locations where homicides occurred, based on latitude and longitude, thus used to create a homicide rate for the coverage areas of the primary health units. These data were provided by the Integrated Center for Social Defense Information of the Minas Gerais State Military Police. Mean family income was obtained from the databases of the Brazilian Institute for Geography and Statistics (IBGE) and was also used as a social environment variable.

Analysis of environmental data began with the Geographic Information System, with the aim of stratifying the geocoded data in layers of information and isolating spatial relations. Cross-analyses of the georeferenced data were translated into variables for the analyses. These procedures were conducted with MapInfo, version 10.5 (MapInfo Corp., New York, USA).

Distribution of cases was analyzed with information on exact location (latitude and longitude), based on the coverage area of the primary health unit (set of territorially demarcated census tracts), which are 147 subdivisions of the nine Health Districts in the city of Belo Horizonte. These areas were proposed considering the boundaries of the census tracts set by IBGE and digitized by Prodabel; for the current study, the coverage area was used as the neighborhood unit. Coverage areas averaged $2.55 \mathrm{~km}^{2}$. The total population was $2,081,147$, with 693,773 households.

Data analysis used the survey module of Stata, version 12 (Stata Corp., College Station, USA), which considers the various aspects of the complex sampling design. The sample was characterized with frequency distribution tables for the target variables according to the subjects' BMI. Environmental variables were described by measures of central tendency and dispersion.

In the univariate and multivariate analyses, the measure of association was prevalence ratio (PR), calculated with the aid of Poisson regression with an estimator of robust variance 30 . Statistical differences were assessed according to the pseudo-likelihood ratio and Wald test. The criterion used for selection of variables in the bivariate analysis was $p \leq 0.20$. After the bivariate analysis, the association was verified between excess weight and the environmental variables adjusted for potential confounding factors: gender, age, conjugal status, and physical inactivity.

\section{Results}

The final sample consisted of 3,425 participants (50.1\% men and $49.9 \%$ women). Mean age was 39.7 years. In relation to the dependent variable, $44 \%$ showed excess weight (BMI $\left.\geq 25 \mathrm{~kg} / \mathrm{m}^{2}\right)$. Of these, $31.6 \%$ were overweight $\left(25 \mathrm{~kg} / \mathrm{m}^{2} \leq \mathrm{BMI}<\right.$ $\left.30 \mathrm{~kg} / \mathrm{m}^{2}\right)$ and $12.4 \%$ were obese $\left(\mathrm{BMI} \geq 30 \mathrm{~kg} / \mathrm{m}^{2}\right)$. Table 2 shows the sample's sociodemographic characteristics.

Table 3 shows the descriptive measures of the target environmental variables. Georeferencing included a total of 174 supermarkets, food marts, and hypermarkets, 171 fruit and vegetable stores, and 107 squares, parks, and locations for physical exercise.

Table 4 shows the prevalence rates and estimators of crude and adjusted associations between the built environment and social environment and excess weight. The crude analysis showed low prevalence rates for excess weight 
Description of environmental variables.

\begin{tabular}{|c|c|c|c|}
\hline Variable & Description & Data Source & Units/Categories \\
\hline Population density & $\begin{array}{c}\text { Population in coverage area/ } \\
\text { coverage area (inhabitants } / \mathrm{km}^{2} \text { ) }\end{array}$ & $\begin{array}{l}\text { IBGE database for Population } \\
\text { Census, } 2000 \text { * }\end{array}$ & $\begin{array}{c}\text { Population density: } \\
\text { 1st tertile (586.6-10.445.8); } \\
2^{\text {nd }} \text { tertile (10.508.2-14.346.4); } \\
\text { 3rd tertile (14.503.0-34.444.4) }\end{array}$ \\
\hline Supermarkets and hypermarkets & $\begin{array}{l}\text { Presence of supermarkets/ } \\
\text { hypermarkets in coverage area }\end{array}$ & $\begin{array}{c}\text { Belo Horizonte CDL for years } 2008 \\
\text { and } 2009\end{array}$ & Presence versus absence \\
\hline Fruit and vegetable stores & $\begin{array}{l}\text { Presence of fruit and vegetable } \\
\text { stores in coverage area }\end{array}$ & $\begin{array}{l}\text { Minas Gerais State CEASA for years } \\
\qquad 2008 \text { and } 2009\end{array}$ & Presence versus absence \\
\hline $\begin{array}{l}\text { Parks, squares, and locations for } \\
\text { physical exercise }\end{array}$ & $\begin{array}{c}\text { Presence of parks, squares, and } \\
\text { locations for physical exercise in } \\
\text { coverage area }\end{array}$ & Prodabel for years 2008 and 2009 & Presence versus absence \\
\hline Homicide rate & $\begin{array}{c}\text { (number of homicides/population } \\
\text { in coverage area) x 1,000 }\end{array}$ & $\begin{array}{l}\text { CINDS, Belo Horizonte Military } \\
\text { Police for years } 2008 \text { and } 2009\end{array}$ & $\begin{array}{l}\text { Homicide rate: } 1 \text { st tertile }(0.1-0.4) ; \\
\text { 2nd tertile }(0.4-0.6) ; \\
\text { 3rd tertile }(0.6-2.2)\end{array}$ \\
\hline Mean family income & $\begin{array}{l}\text { Mean family income in } \\
\text { coverage area (in reais) }\end{array}$ & $\begin{array}{l}\text { IBGE database for Population } \\
\text { Census, } 2000 \text { * }\end{array}$ & $\begin{array}{c}\text { Mean family income: } \\
\text { 1st tertile }(1,281.3-2,780.2) \\
\text { 2nd tertile }(2,820.3-5,066.7) \\
\text { 3rd tertile }(5,210.1-15,284.0)\end{array}$ \\
\hline
\end{tabular}

CDL: Belo Horizonte Chamber of Commerce; CEASA: Minas Gerais Food Produce Central Warehouse; CINDS: Integrated Center for Social Defense Data; IBGE: Brazilian Institute of Geography and Statistics; Prodabel: Belo Horizonte Municipal Company for Information and Information Technology;

SMS: Belo Horizonte Municipal Health Secretariat.

* At the time of the study, the results of the 2010 Population Census had still not been published.

in neighborhoods with higher population density. Adjustment for gender, age, conjugal status, and physical inactivity showed lower prevalence of excess weight in neighborhoods with higher population density and those with squares and other locations for physical exercise $(\mathrm{p}<0.05)$.

\section{Discussion}

The study's results illustrate the independent relationship between environmental variables and excess weight. Higher population density and the presence of parks, squares, and other locations for physical exercise were associated with lower prevalence of excess weight.

This study showed that living in neighborhoods with higher population density (3rd tertile) was associated with lower prevalence of excess weight, an association that was maintained after adjusting for gender, age, and conjugal status. Neighborhoods with high population density often display mixed land use and greater connectivity between streets. They are thus more amenable to circulating on foot, which can be related to lower BMI 10,31,32.
Studies in North American cities 33,34 found that persons living in neighborhoods with higher population density showed significantly lower BMI than those living in areas with low population density. An inverse association was seen between BMI and mixed land use, number of bus and subway stops, and number of street intersections. This suggests that higher population density in the neighborhood is associated with more circulation on foot, such that individuals living in neighborhoods with higher population density used automobiles less and consequently engage in more physical activity by walking back and forth on a routine basis, thus presenting lower obesity prevalence 34 .

The current study also showed associations with the presence of parks, squares, and locations for physical exercise in the neighborhood. Recent studies have suggested that parks, squares, and other green spaces for recreation in neighborhoods are important places for people to be more physically active 35 , especially in urban areas where access to green spaces is more limited 36. There is also evidence that improved availability and access to green spaces for recreation in urban areas can be an effective public health measure, 
Socio-demographic characteristics of the total sample and according to body mass index (BMI) for the city of Belo Horizonte, Minas Gerais State, Brazil, 2008 and 2009

\begin{tabular}{|c|c|c|c|c|}
\hline \multirow[t]{2}{*}{ Variables } & \multicolumn{2}{|c|}{ Total } & \multicolumn{2}{|c|}{$\mathrm{BMI} \geq 25 \mathrm{~kg} / \mathrm{m}^{2}$} \\
\hline & $\%$ & $95 \% \mathrm{Cl}$ & $\%$ & $95 \% \mathrm{Cl}$ \\
\hline \multicolumn{5}{|l|}{ Gender } \\
\hline Male & 50.1 & $47.5-52.7$ & 46.9 & $43.1-50.6$ \\
\hline Female & 49.9 & $47.3-52.5$ & 41.1 & $37.5-44.8$ \\
\hline \multicolumn{5}{|l|}{ Age (years) } \\
\hline $18-24$ & 19.4 & $16.8-22.5$ & 22.5 & $14.5-33.2$ \\
\hline $25-34$ & 23.5 & $21.3-26.0$ & 41.2 & $35.4-47.3$ \\
\hline $35-44$ & 22.8 & $21.0-24.7$ & 48.1 & $43.9-52.4$ \\
\hline $45-54$ & 15.7 & $14.2-17.0$ & 53.2 & $48.7-57.6$ \\
\hline $55-64$ & 10.0 & $9.0-11.2$ & 60.7 & $55.5-65.6$ \\
\hline$\geq 65$ & 8.6 & $7.6-9.5$ & 53.0 & $47.7-58.2$ \\
\hline \multicolumn{5}{|l|}{ Skin color } \\
\hline White & 34.3 & $32.1-36.5$ & 42.4 & $39.2-45.0$ \\
\hline Non-white & 65.7 & $63.5-67.9$ & 44.9 & $41.3-48.5$ \\
\hline \multicolumn{5}{|l|}{ Conjugal status } \\
\hline Single & 43.0 & $40.2-45.7$ & 34.4 & $29.6-39.7$ \\
\hline Married/Stable union & 47.6 & $45.1-50.2$ & 50.5 & $47.6-53.4$ \\
\hline Other: separated, divorced, widowed & 9.4 & 8.3-10.7 & 54.6 & $48.4-60.6$ \\
\hline \multicolumn{5}{|l|}{ Schooling (years of school) } \\
\hline$\leq 4$ & 17.0 & $14.6-19.8$ & 50.8 & $42.2-59.4$ \\
\hline $5-8$ & 30.8 & $28.1-33.6$ & 46.5 & $40.9-52.2$ \\
\hline $9-11$ & 31.6 & $29.6-33.7$ & 41.6 & $38.6-44.7$ \\
\hline$\geq 12$ & 20.6 & $19.1-22.2$ & 37.0 & $34.2-41.0$ \\
\hline
\end{tabular}

95\% Cl: 95\% confidence interval.

Table 3

Description of variables in the social environment and built environment by coverage area.

\begin{tabular}{|c|c|c|c|c|c|}
\hline Variables & Mean & Median & $\begin{array}{l}\text { Standard } \\
\text { error }\end{array}$ & Minimum & Maximum \\
\hline Mean family income (R\$) & $4,661.3$ & $3,692.7$ & $2,948.4$ & $1,281.3$ & $15,284.0$ \\
\hline Population density (inhabitants/km²) & $11,806.8$ & $11,766.7$ & $5,010.1$ & 586.6 & $34,444.4$ \\
\hline Number of hyper and supermarkets & 4.7 & 3.0 & 5.1 & 0.0 & 24.0 \\
\hline Number of fruit and vegetable stores & 1.3 & 1.0 & 1.5 & 0.0 & 6.0 \\
\hline Number of squares, parks, and locations for physical exercise & 4.9 & 3.0 & 5.5 & 0.0 & 25.0 \\
\hline
\end{tabular}

encouraging greater participation in leisure-time activities and thus reducing the risk of overweight and obesity 37,38 .

A study in the city of Curitiba, Paraná State, Brazil, with objective measures of the built environment found that adults living in neighborhoods with higher income, more gyms, and closer proximity to recreational and sports centers were more capable of following recommendations for leisure-time walking. However, the density of recreational infrastructures such as bicycle lanes, parks, wooded areas, and squares was not statistically associated with physical activity in the study 39 . 
Prevalence rates and crude and adjusted associations between variables from the built environment and social environment and excess weight.

\begin{tabular}{|c|c|c|c|}
\hline Variables $(n)$ * & $\begin{array}{c}\text { BMI } \geq 25 \mathrm{~kg} / \mathrm{m}^{2} \\
(\%)\end{array}$ & $\begin{array}{l}\text { Crude PR } \\
(95 \% \mathrm{Cl})\end{array}$ & $\begin{array}{l}\text { Crude PR ** } \\
\qquad(95 \% \mathrm{Cl})\end{array}$ \\
\hline \multicolumn{4}{|l|}{ Built environment } \\
\hline \multicolumn{4}{|l|}{ Model 1} \\
\hline \multicolumn{4}{|c|}{ Presence of supermarkets/hypermarkets } \\
\hline No (33) & 44.8 & 1.00 & 1.00 \\
\hline Yes (114) & 43.8 & $0.97(0.83-1.14)$ & $0.97(0.83-1.14)$ \\
\hline \multicolumn{4}{|l|}{ Model 2} \\
\hline \multicolumn{4}{|c|}{ Presence of fruit and vegetable stores } \\
\hline No (79) & 42.9 & 1.00 & 1.00 \\
\hline Yes (68) & 44.8 & $1.04(0.93-1.17)$ & $1.03(0.91-1.16)$ \\
\hline \multicolumn{4}{|l|}{ Model 3} \\
\hline \multicolumn{4}{|c|}{ Presence of parks, squares, and locations for physical exercise } \\
\hline No (36) & 48.7 & 1.00 & 1.00 \\
\hline Yes (111) & 43.2 & $0.88(0.76-1.03)$ & $0.86(0.73-0.99)$ \\
\hline \multicolumn{4}{|l|}{ Model 4} \\
\hline \multicolumn{4}{|l|}{ Population density } \\
\hline 1st tertile (57) & 54.0 & 1.00 & 1.00 \\
\hline $2^{\text {nd }}$ tertile (45) & 54.0 & $1.00(0.86-1.16)$ & $1.03(0.88-1.19)$ \\
\hline 3 rd tertile (45) & 61.0 & $0.85(0.75-0.97)$ & $0.87(0.77-0.99)$ \\
\hline \multicolumn{4}{|l|}{ Social environment } \\
\hline \multicolumn{4}{|l|}{ Model 5} \\
\hline \multicolumn{4}{|l|}{ Homicide rate } \\
\hline 1st tertile (37) & 58.0 & 1.00 & 1.00 \\
\hline 2nd tertile (49) & 54.0 & $1.09(0.96-1.25)$ & $1.09(0.97-1.25)$ \\
\hline 3rd tertile (61) & 56.0 & $1.06(0.90-1.23)$ & $1.09(0.93-1.27)$ \\
\hline \multicolumn{4}{|l|}{ Model 6} \\
\hline \multicolumn{4}{|c|}{ Mean family income } \\
\hline 1st tertile (61) & 56.0 & 1.00 & 1.00 \\
\hline 2nd tertile (44) & 57.0 & $0.99(0.87-1.13)$ & $0.97(0.86-1.09)$ \\
\hline 3rd tertile (42) & 54.0 & $1.00(0.85-1.17)$ & $0.99(0.82-1.18)$ \\
\hline
\end{tabular}

95\% Cl: 95\% confidence interval; PR: prevalence ratio.

* Values in parentheses are numbers of neighborhoods in each category;

** PR adjusted for gender, age, conjugal status, and physical inactivity.

Note: The above models are independent, i.e., a single model does not contain more than one environmental variable.

For variables related to the social environment, no associations were observed, but other studies have shown that living in economically underprivileged neighborhoods is related to higher BMI and greater weight gain, and other studies have found that the odds ratio of overweight increased with the neighborhood's deprivation 40,41,42.

Some findings from previous studies further suggested that the neighborhood's socioeconomic environment may be related to the prevalence of excess weight through mediators related to the built environment 43 . Thus, economically privileged neighborhoods show a higher absolute number and density of commercial establishments such as supermarkets and fruit and vegetable stores, which in turn are associated with greater availability of, access to, and consumption of healthy foods and lower overweight and obesity rates 44 .

Interestingly, when the current study explored the contributions by the built environment to the availability of specialized stores for healthy food in the neighborhoods, no statistical associations with excess weight were observed. Studies in devel- 
oped countries have shown that characteristics of the food environment, such as the type and size of food stores, are important factors associated with neighborhood food quality in large cities, but contradictory results have been found when the outcome is excess weight $44,45,46,47$.

This study is subject to some limitations. First, despite the use of a causal model, the cross-sectional design does not allow such conclusions. The second limitation, inherent to the methodological proposal due to its practicality in health surveillance systems, results from the self-reported measurement of the dependent variable. However this limitation is minimized by validation studies conducted with participants from the VIGITEL sample, which showed high correlation indices when the measurements were compared to self-reported values and good sensitivity and specificity 29 . A third limitation relates to the geo- referenced data used to describe the characteristics of the built and social environments, which are secondary data and thus subject to imprecision. An additional limitation is in the sample, consisting of persons living in households with landline telephones. Still, sampling weights were used in the data analysis to adjust the sample to the Brazilian population's social and demographic composition.

The evidence in this study showed that the characteristics of the built environment presented significant associations with excess weight, even after adjusting for gender, age, and conjugal status. These findings are preliminary and require further studies in other Brazilian cities to confirm the relevance of neighborhood environments in the causal web of the current obesity epidemic and to develop effective strategies for the prevention of obesity in the Brazilian context.

\section{Resumen}

El objetivo de este estudio fue evaluar asociaciones entre variables de ambiente construido y social con el exceso de peso en una población urbana. Los participantes fueron seleccionados a partir de un Sistema de Vigilancia de las Enfermedades Crónicas (VIGITEL). El estudio utilizó 3.425 entrevistas, realizadas en 2008 y 2009 , en la ciudad de Belo Horizonte, Minas Gerais, Brasil. Adicionalmente, para evaluar el ambiente físico se incorporó a la base de datos información georreferenciada de los parques, lugares para la actividad física, densidad de población, establecimientos de venta de alimentos y aspectos de ambiente social mediante tasas de homicidio en el vecindario. Las variables ambientales que fueron asociadas de forma independiente al sobrepeso fueron: densidad poblacional, presencia de parques, plazas y lugares para la actividad física y también el autorrelato de presencia de lugares para la práctica de actividad física. Este estudio muestra evidencias que las características de la vecindad, donde residen las personas, pueden estar asociadas al exceso de peso en adultos.

Medio Ambiente Controlado; Medio Ambiente y Salud Pública; Obesidad; Sobrepeso

\section{Contributors}

G. Velásquez-Meléndez and L. L. Mendes participated in the study's conceptualization and analysis and writing of the article. C. M. P. Padez collaborated in the critical revision of the intellectual content.

\section{Acknowledgments}

The authors wish to thank FAPEMIG, CNPq, and the Brazilian Ministry of Health for funding the research project. 


\section{References}

1. World Health Organization. Obesity and overweight. (Fact sheet, 311). http://www.who.int/me diacentre/factsheets/fs311/en/ (accessed on 12/ Jan/2012).

2. Handy SL, Boarnet MG, Ewing R, Killingsworth RE. How the built environment affects physical activity: views from urban planning. Am J Prev Med 2002; 23 Suppl 2:S64-73.

3. Janssen I, Boyce WF, Simpson K, Pickett W. Influence of individual and area level measures of socioeconomic status on obesity, unhealthy eating, and physical inactivity in Canadian adolescents. Am J Clin Nutr 2006; 83:139-45.

4. Popkin B, Duffey K, Gordon-Larsen P. Environmental influences on food choice, physical activity and energy balance. Physiol Behav 2005; 86:603-13.

5. Swinburn B, Egger G, Raza F. Dissecting obesogenic environments: the development and application of a framework for identifying and prioritizing environmental interventions for obesity. Am J Prev Med 1999; 29:563-70.

6. Bouchard C. The biological predisposition to obesity: beyond the thrifty genotype scenario. Int $\mathrm{J}$ Obes 2007; 31:1337-9.

7. Feng J, Glass TA, Curriero FC, Stewart WF, Schwartz BS. The built environment and obesity: a systematic review of the epidemiologic evidence. Health Place 2010; 16:175-90.

8. McCormack G, Giles-Corti B, Lange A, Smith T, Martin K, Pikora TJ. An update of recent evidence of the relationship between objective and selfreport measures of the physical environment and physical activity behaviours. J Sci Med Sport 2004; 7(1 Suppl):81-92.

9. Zenk SN, Schulz AJ, Hollis-Neely T, Campbell RT, Holmes N, Watkins G, et al. Fruit and vegetable intake in African Americans: income and store characteristics. Am J Prev Med 2005; 29:1-9.

10. Saelens BE, Sallis JF, Frank LD. Environmental correlates of walking and cycling: findings from the transportation, urban design, and planning literatures. Ann Behav Med 2003; 25:80-91.

11. Black JL, Macinko J. Neighbourhoods and obesity. Nutr Rev 2008; 66:2-20.

12. Booth KM, Pinkston MM, Poston WS. Obesity and the built environment. J Am Diet Assoc 2005; 105(5 Suppl 1):S110-7.

13. Frumkin H. Urban sprawl and public health. Public Health Rep 2002; 117:201-17.

14. Papas MA, Alberg AJ, Ewing R, Helzlsouer KJ, Gary TL, Klassen AC. The built environment and obesity. Epidemiol Rev 2007; 29:129-43.

15. Ewing R, Schmid T, Killingsworth R, Zlot A, Raudenbush S. Relationship between urban sprawl and physical activity, obesity, and morbidity. Am J Health Promot 2003;18:47-57.

16. Zhao Z, Kaestner R. Effects of urban sprawl on obesity. J Health Econ 2010; 29:779-87.

17. Macintyre S, Ellaway A, Cummins S. Place effects on health: how can we conceptualise, operationalise and measure them? Soc Sci Med 2002; 55: 125-39.
18. Hill JO, Wyatt HR, Melanson EL. Genetic and environmental contributions to obesity. Med Clin North Am 2000; 84:333-46.

19. Peters JC. Combating obesity: challenges and choices. Obes Res 2003; 11Suppl:7S-11S.

20. Swinburn BA, Caterson I, Seidell JC, James WPT. Diet, nutrition and the prevention of excess weight gain and obesity. Public Health Nutr 2004; 7:123-46.

21. Kirk SFL, Penney TL, McHugh TLF. Characterizing the obesogenic environment: the state of the evidence with directions for future research. Obes Rev 2010; 11:109-17.

22. Ball K, Timperio AF, Crawford DA. Understanding environmental influences on nutrition and physical activity behaviors: where should we look and what should we count? Int J Behav Nutr Phys Act 2006; 3:33.

23. Giskes K, van Lenthe F, Avendano-Pabon M, Brug J. A systematic review of environmental factors and obesogenic dietary intakes among adults: are we getting closer to understanding obesogenic environments? Obes Rev 2011; 12:e95-106.

24. Lovasi GS, Hutson MA, Guerra M, Neckerman KM. Built environments and obesity in disadvantaged populations. Epidemiol Rev 2009; 31:7-20.

25. Secretaria de Gestão Estratégica e Participativa, Secretaria de Vigilância em Saúde, Ministério da Saúde. VIGITEL Brasil 2008: vigilância de fatores de risco e proteção para doenças crônicas por inquérito telefônico. Brasília: Ministério da Saúde; 2009. (Série G. Estatística e Informação em Saúde).

26. Secretaria de Gestão Estratégica e Participativa, Secretaria de Vigilância em Saúde, Ministério da Saúde. VIGITEL Brasil 2009: vigilância de fatores de risco e proteção para doenças crônicas por inquérito telefônico. Brasília: Ministério da Saúde; 2010. (Série G. Estatística e Informação em Saúde).

27. World Health Organization. Obesity: preventing and managing the global epidemic. Geneva: World Health Organization; 1998. (Technical Report Series, 894).

28. Gorber SC, Tremblay M, Moher D, Gorber B. Comparison of direct vs. self-report measures for assessing height, weight and body mass index: a systematic review. Obes Rev 2007; 8:307-26.

29. Lucca A, Moura EC. Validity and reliability of selfreported weight, height and body mass index from telephone interviews. Cad Saúde Pública 2010; 26:110-22.

30. Barros AJ, Hirakata VN. Alternatives for logistic regression in cross-sectional studies: an empirical comparison of models that directly estimate the prevalence ratio. BMC Med Res Methodol 2003; $3: 21$.

31. Frank LD, Andresen MA, Schmid TL. Obesity relationships with community design, physical activity, and time spent in cars. Am J Prev Med 2004; 27:87-96.

32. Saelens BE, Handy SL. Built environment correlates of walking: a review. Med Sci Sports Exerc 2008; 40 Suppl:S550-66. 
33. Rundle A, Roux, AVD, Freeman LM, Miller D, Neck erman KM, Weiss CC. The urban built environment and obesity in New York City: a multilevel analysis. Am J Health Promot 2007; 21 (4 Suppl):326-34.

34. Lopez RP. Neighborhood risk factors for obesity. Obesity (Silver Spring) 2007; 15:2111-9.

35. Macintyre S, Macdonald L, Ellaway A. Lack of agreement between measured and self-reported distance from public green parks in Glasgow, Scotland. Int J Behav Nutr Phys Act 2008; 5:26.

36. Maas J, Verheij RA, Groenewegen PP, Vries S, Spreeuwenberg P. Green space, urbanity, and health: how strong is the relation? J Epidemiol Community Health 2006; 60:587-92.

37. Coombes E, Jones AP, Hillsdon M. The relationship of physical activity and overweight to objectively measured green space accessibility and use. Soc Sci Med 2010; 70:816-22.

38. Lee AC, Maheswaran R. The health benefits of urban green spaces: a review of the evidence. J Public Health 2011; 33:212-22.

39. Hino AAF, Reis RS, Sarmiento OL, Parra DC, Brownson RC. The built environment and recreational physical activity among adults in Curitiba, Brazil. Am J Prev Med 2011; 52:419-22.

40. Stafford M, Brunner EJ, Head J, Ross NA. Deprivation and the development of obesity a multilevel, longitudinal study in England. Am J Prev Med 2010; 39:130-9.

41. Wang MC, Kim S, Gonzalez AA, MacLeod KE, Winkleby MA, Marilyn A. Socioeconomic and food-related physical characteristics of the neighborhood environment are associated with body mass index. J Epidemiol Community Health 2007; 61:491-8.
42. Giskes K, van Lenthe FJ, Turrell G, Kamphuis CB, Brug J, Mackenbach JP. Socioeconomic position at different stages of the life course and its influence on body weight and weight gain in adulthood: a longitudinal study with 13-year follow-up. Obesity (Silver Spring) 2008; 16:1377-81.

43. Bodor JN, Rose D, Farley T, Swalm C, Scott S. Neighborhood fruit and vegetable availability and consumption: the role of small food stores in an urban environment. Public Health Nutr 2008; 11:413-20.

44. Pearce J, Hiscock R, Blakely T, Witten K. The contextual effects of neighbourhood access to supermarkets and convenience stores on individual fruit and vegetable consumption. J Epidemiol Community Health 2008; 62:198-201.

45. Bovell-Benjamin AC, Hathorn CS, Ibrahim S, Gichuhi PN, Bromfield EM. Healthy food choices and physical activity opportunities in two contrasting Alabama cities. Health Place 2009; 15:429-38.

46. Walker RE, Keane CR, Burke JG. Disparities and access to healthy food in the United States: a review of food deserts literature. Health Place 2010; 16:876-84

47. Bodor JN, Rice JC, Farley TA, Swalm CM, Rose D. The association between obesity and urban food environments. J Urban Health 2010; 87:771-81.

Submitted on $01 /$ Jun/2012

Final version resubmitted on $11 / \mathrm{Jan} / 2013$

Approved on 02/Apr/2013 